\title{
Przetoki naczyniowe w praktyce kardiologicznej - wspólny obszar zainteresowania współczesnej kardiologii interwencyjnej i kardiochirurgii
}

\author{
Vascular fistulas in cardiac practice - common interest \\ in contemporary interventional cardiology and cardiac surgery
}

\author{
Magdalena Słupska ${ }^{1}$, Paweł Cześniewicz ${ }^{1}$, Jacek Kusa ${ }^{1,2}$ \\ ${ }^{1}$ Oddział Kardiologii Dziecięcej Wojewódzkiego Szpitala Specjalistycznego we Wrocławiu \\ ${ }^{2}$ Katedra i Klinika Kardiologii Dziecięcej Śląskiego Uniwersytetu Medycznego w Katowicach
}

\section{Streszczenie}

Przetoki naczyniowe są nieprawidłowymi połączeniami naczyniowymi o charakterze wrodzonym lub nabytym. Ze względu na zróżnicowany obraz kliniczny pozostają w obszarze zainteresowania lekarzy różnych specjalności w zależności od lokalizacji i odmiany morfologicznej. Celem niniejszej pracy jest przedstawienie najczęściej występujących typów przetok istotnych z punktu widzenia kardiologów z uwzględnieniem etiologii, objawów oraz współczesnych metod diagnostyki i leczenia.

Słowa kluczowe: przetoki naczyniowe, kardiologia, leczenie przezskórne

Folia Cardiologica 2017; 12; 5: 510-516

\section{Przetoki naczyniowe}

Przetoki naczyniowe to nieprawidłowe połączenia tętniczo-żylne, tętniczo-tętnicze i żylno-żylne [1]. Występują w różnych okolicach ciała i mają zróżnicowany obraz kliniczny. Domeną kardiologów pozostają przede wszystkim przetoki będące przyczyną zaburzeń hemodynamicznych, niewydolności serca, niedokrwienia mięśnia sercowego, sinicy i incydentów zatorowych. Szczególną grupę stanowią nieprawidłowe połączenia naczyniowe powstające u pacjentów ze złożonymi siniczymi wadami serca po paliatywnych zabiegach kardiochirurgicznych, a także przetoki jatrogenne, będące powikłaniem zabiegów interwencyjnych [2].

Najczęściej występują przetoki tętniczo-żylne. Są to nieprawidłowe, bezpośrednie połączenia między tętnicami i żyłami, z pominięciem krążenia kapilarnego [1, 3]. Dzieli się je na: systemowe, wewnątrzpłucne i wieńcowe. W każdej z tych podgrup można wyróżnić przetoki wrodzone lub nabyte (jatrogenne, pozapalne, pourazowe).

\section{Systemowe przetoki tętniczo-żylne}

Zwykle są umiejscowione w ośrodkowym układzie nerwowym (OUN), wątrobie lub kończynach. Mogą być pojedyncze lub mnogie. Stopień powodowanych przez nie zaburzeń hemodynamicznych i nasilenie objawów, zarówno ogólnych, jak i miejscowych, zależą od ich lokalizacji i wielkości. Zasadniczym następstwem hemodynamicznym dużej przetoki jest istotny przeciek lewo-prawy z tętnicy (naczynia wysokociśnieniowego) do żyły (naczynia niskociśnieniowego) i w rezultacie obniżenie obwodowego oporu systemowego, zwiększenie rzutu serca i objętości krwi krążącej. W wyniku krążenia hiperkinetycznego dochodzi do rozwoju niewydolności serca z wysokim rzutem [2-4]. 
Objawy dużej przetoki w badaniu przedmiotowym to: wysoka amplituda tętna, niskie ciśnienie rozkurczowe, hiperkinetyczne uderzenie koniuszkowe, rytm cwałowy, tachykardia, szmer skurczowy w okolicy przedsercowej z powodu zwiększonego przepływu przez zastawki półksiężycowate, drżenie i szmer ciągły lub skurczowy nad przetoką i różnica w wypełnieniu tętna na tętnicach obwodowych w zależności od ich usytuowania w stosunku do przetoki - proksymalnie dobrze wypełnione, dystalnie zaś słabo [2-4]. Inne objawy w badaniu fizykalnym obejmują: szyjne buczenie żylne, objaw Traubego - głośny ton porównywany do wystrzału z pistoletu nad tętnicą udową w skurczu i rozkurczu, oraz puls Quinckego - rytmiczne blednięcie i czerwienienie płytki paznokciowej przy lekkim ucisku. Przejściowy ucisk przetoki powoduje wzrost ciśnienia tętniczego, obniżenie ciśnienia żylnego i zwolnienie częstości rytmu serca (objaw Nicoladoni-Brannhama) [4].

Przetoka może spowodować zespół podkradania krwi z położonych dystalnie w stosunku do niej obszarów i w efekcie niedokrwienie i martwice tkanek. Ucisk na sąsiadujące struktury, tak zwany efekt masy, również powoduje hipoperfuzję i upośledzenie funkcji narządów. W wyniku wzrostu ciśnienia w łożysku żylnym często dochodzi do rozwoju żylaków [1-3].

Kolejny objaw to krwawienia w wyniku pękania cienkiej ściany przetoki, będące szczególnie istotnym problemem w przypadku zmian zlokalizowanych w OUN. Tętniczo-żylne malformacje naczyniowe w mózgu odpowiadają za 9\% krwawień do mózgowia i 2\% udarów. Średni czas życia pacjentów z tymi patologiami nie przekracza czterdziestu kilku lat. Objawy malformacji wewnątrzczaszkowych (bóle i zawroty głowy, zaburzenia równowagi, drgawki, zaburzenia neurologiczne) wiążą się również z mniejszą dostawą tlenu do tkanki mózgowej i z uciskiem na mózgowie [1, 2]. Przykładem przetoki tętniczo-żylnej w OUN jest malformacja żyły Galena, wiążąca się z wysoką śmiertelnością w okresie noworodkowym, powodująca objawy niewydolności serca i krwotoku wewnątrzczaszkowego [5].

Przetoki w wątrobie to nieprawidłowe połączenia wrotno-systemowe (między żyłą wrotną i żyłą wątrobową lub żyłą główną dolną), tętniczo-wrotne (między tętnicą wątrobową i żyłą wrotną) oraz tętniczo-systemowe (między tętnicą wątrobową i żyłą wątrobową). Przetoki tętniczo-wrotne mogą być wrodzone, na przykład w chorobie Rendu-Oslera-Webera (HHT, hereditary hemorrhagic telangiectasia), lub nabyte w chorobach wątroby, między innymi w przypadku marskości, nowotworach, po urazach [6, 7]. Mogą być przyczyną niewydolności serca z wysokim rzutem i nadciśnienia wrotnego $[1,6,7]$.

Przetoki tętniczo-żylne zlokalizowane w kończynach najczęściej manifestują się miejscowo, rzadko ogólnoustrojowo. Z reguły powodują obrzęk kończyny i wzmożone ucieplenie, a także zaburzenie rozwoju z asymetrią wielkości kończyn i zmiany troficzne w wyniku zespołu podkrada- nia [1, 2]. Zdecydowaną większość stanowią przetoki pourazowe, nieco rzadziej występują przetoki jatrogenne, najrzadziej zaś - wrodzone. Przetoki jatrogenne powstają jako powikłanie nakłucia tętnicy udowej podczas badania angiograficznego. Spowodowane są zazwyczaj zbyt niskim nakłuciem - poniżej podziału tętnicy udowej wspólnej na tętnice udową powierzchowną i tętnice głęboką uda. Występują u około $1 \%$ pacjentów cewnikowanych i są rzadszym powikłaniem niż pseudotętniak, krwiak i skrzeplina [6].

\section{Przetoki wieńcowe}

Przetoka wieńcowa to połączenie jednej lub kilku tętnic wieńcowych z jamą serca albo naczyniami krążenia systemowego bądź płucnego, z pominięciem sieci naczyń włosowatych. Najczęściej jest to wada wrodzona, ale w rzadkich przypadkach może mieć charakter nabyty w wyniku przezskórnych interwencji wieńcowych lub urazów penetrujących klatkę piersiową, takich jak rany kłute $[2,8,9]$.

Zazwyczaj przetoki wrodzone są wadami izolowanymi; mogą jednak towarzyszyć wrodzonym wadom serca, takim jak zespół Fallota, przetrwały przewód tętniczy i ubytek przegrody międzyprzedsionkowej [10]. Przetokę tętnicy wieńcowej stwierdza się w około 0,3-0,8\% koronarografii [8]. Najczęściej wychodzi z prawej tętnicy wieńcowej (52\%), rzadziej - od gałęzi przedniej zstępującej lewej tętnicy wieńcowej (30\%), a najrzadziej - od tętnicy okalającej (18\%). Przetoki drenują przeważnie do niskociśnieniowych jam serca lub dużych naczyń - około 90\% przetok uchodzi do jam prawego serca, a tylko 10\% do jam lewego serca [9]. Ich ujście dystalne jest najczęściej zlokalizowane w prawej komorze (41\%), rzadziej: w prawym przedsionku (26\%), tętnicy płucnej (17\%), lewej komorze (3\%), zatoce wieńcowej (7\%), a najrzadziej - w żyle głównej górnej (1\%) [8].

Objawy zależą od miejsca wyjścia przetoki, jej wielkości oraz miejsca odpływu krwi, a także od wieku pacjenta. Przetoki wieńcowe najczęściej są bezobjawowe w pierwszych 2 dekadach życia, szczególnie jeśli są małe [9]. W niewielkim odsetku mogą ulec samoistnemu zamknięciu [8], niekiedy jednak mogą wywoływać objawy już w okresie niemowlęcym. Istotne hemodynamicznie przeważnie są przetoki uchodzące do jam prawego serca. Objawy wynikają z narastania lewo-prawego przecieku, co może prowadzić do niewydolności serca związanej z przeciążeniem objętościowym i do rozwoju nadciśnienia płucnego. W wyniku zmniejszonego przepływu wieńcowego dystalnie od przetoki (zespół podkradania) mogą wystąpić niedokrwienie lub zawał serca. Inne powikłania to: powstawanie skrzeplin w świetle przetoki, prowadzące niekiedy do epizodów ostrego niedokrwienia, oraz pęknięcie tętniakowatego poszerzenia przetoki i tamponada osierdzia. Przetoki mogą także odpowiadać za rozwój infekcyjnego zapalenia wsierdzia i zaburzeń rytmu [2, 8-10]. 
U pacjentów bezobjawowych podejrzenie przetoki wieńcowej sugeruje szmer ciągły podobny do szmeru przetrwałego przewodu tętniczego, ale zlokalizowany w okolicy przedsercowej (a nie podobojczykowej - typowej dla przetrwałego przewodu tętniczego [PDA, patent ductus arteriosus]) i głośniejszy w rozkurczu [9].

\section{Płucne przetoki tętniczo-żylne}

Płucne przetoki tętniczo-żylne to nieprawidłowe połączenia między tętnicami i żyłami w łożysku płucnym, z pominięciem krążenia włośniczkowego. Najczęściej mają charakter wrodzony i w większości przypadków (60\%) związane są z wrodzoną naczyniakowatością krwotoczną (HHT, hereditary hemorrhagic telangiectasia) [11]. Jest to choroba dziedziczona autosomalnie dominująco, spowodowana mutacją genu endogliny, białka wiążącego transformujący czynnik wzrostu beta (TGF- $\beta$, transforming growth factor $\beta$ ), i charakteryzująca się zaburzeniami angiogenezy [12]. Kryteria diagnostyczne choroby HHT to: rodzinny wywiad wrodzonej naczyniakowatości krwotocznej, nawracające krwawienia z nosa, teleangiektazje na skórze i błonach śluzowych oraz malformacje tętniczo-żylne lub przetoki, między innymi w OUN, płucach, wątrobie, przewodzie pokarmowym i drogach moczowych $[2,13]$. Częstość występowania malformacji tętniczo-żylnych w płucach u chorych z tym zespołem wynosi 15-33\% [6].

Nabyte płucne przetoki tętniczo-żylne występują u pacjentów z chorobami wątroby, a także po paliatywnych ze- spoleniach kardiochirurgicznych u pacjentów z wrodzonymi wadami serca o typie czynnościowo pojedynczej komory. Mogą również wystąpić po urazach [11].

Zmiany mogą być izolowane - jak we wrodzonych płucnych przetokach tętniczo-żylnych - lub rozsiane - jak w chorobach wątroby i we wrodzonych wadach serca. Różnią się wielkością: od niewielkich - 1-2 mm (mikroprzetoki), do dużych, obejmujących niekiedy całe płuco (makroprzetoki). Przetoki duże to w większości przetoki pojedyncze, zlokalizowane w dolnych płatach płuc [2] (ryc. 1).

Szczególna postać rozsianych płucnych przetok tętniczo-żylnych występuje u pacjentów ze złożonymi siniczymi wadami serca po dwukierunkowym zespoleniu Glenna, polegającym na zespoleniu końca żyły głównej górnej do boku gałęzi płucnej po tej samej stronie, z pozostawieniem spływu z żyły głównej dolnej do krążenia systemowego. W tym układzie oba płuca otrzymują krew żylną pozbawioną spływu z żył wątrobowych. Za przyczynę powstawania przetok tętniczo-żylnych w płucach w tych przypadkach uważa się brak hipotetycznego „czynnika wątrobowego" - inhibitora angiogenezy - we krwi napływającej do układu płucnego [11, 12, 14, 15]. Za udziałem wątroby przemawia powstawanie obustronnych płucnych przetok tętniczo-żylnych u pacjentów z zespołem heterotaksji/ polisplenii (z przerwaniem żyły głównej dolnej i ujściem żył wątrobowych bezpośrednio do przedsionka), u których wykonano operację Kawashima (zespolenie Glenna z powrotem krwi z dolnej części ciała do żyły głównej górnej przez żyłę nieparzystą). U tych chorych oba płuca są poz-
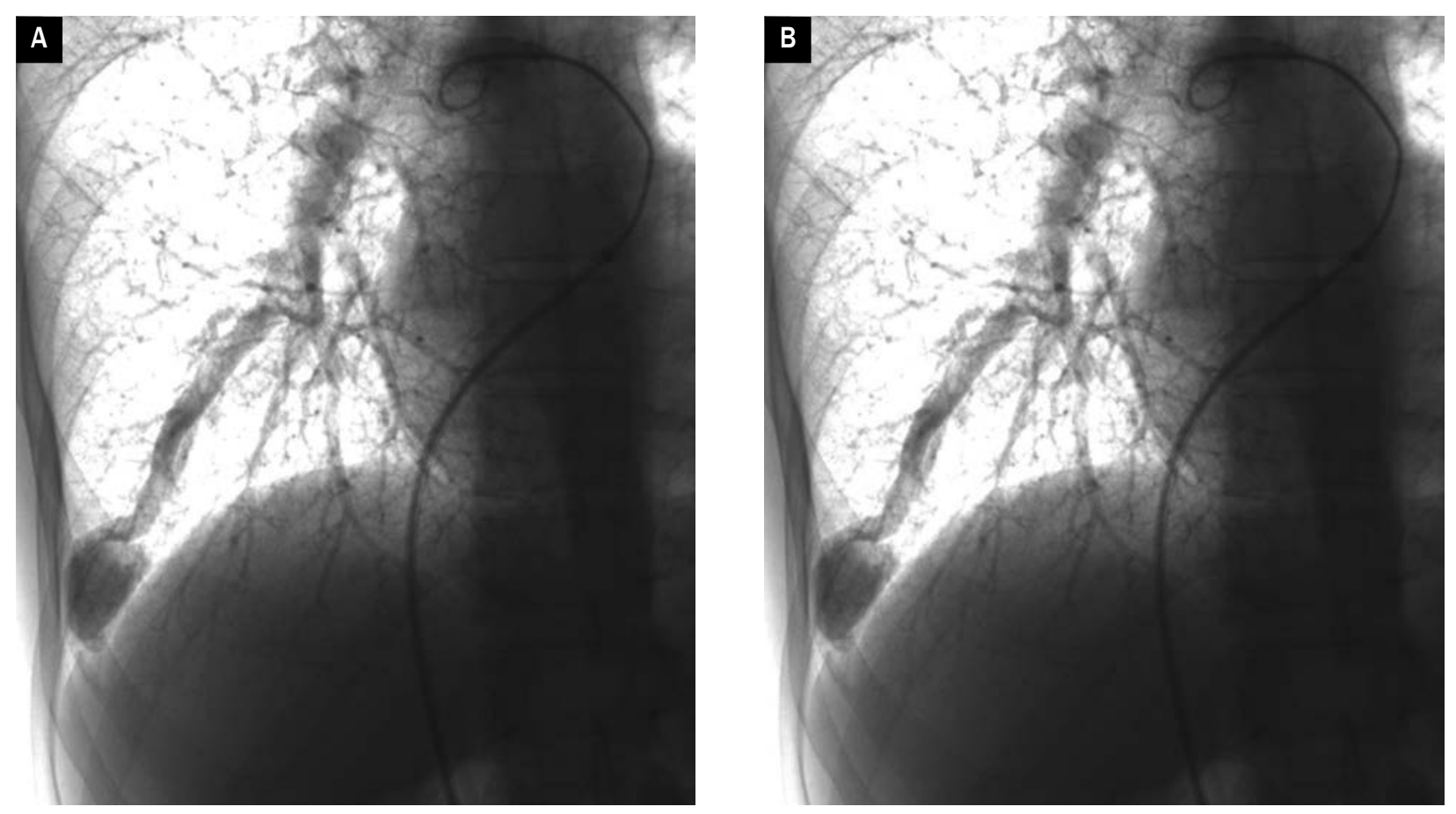

Rycina 1A. Płucna przetoka tętniczo-żylna w dolnym płacie płuca prawego; B. Stan po przezskórnym zamknięciu płucnej przetoki tętniczo-żylnej przy użyciu amplatzer vascular plug 
bawione napływu krwi wątrobowej. Istnieją doniesienia o całkowitym ustępowaniu płucnej przetoki tętniczo-żylnej po wykonaniu u tych pacjentów operacji skierowania żył wątrobowych do układu płucnego $[12,14]$. Dowodem na udział „czynnika wątrobowego" w powstawaniu płucnych przetok tętniczo-żylnych może być również obecność przetok tętniczo-żylnych w prawym płucu, pozbawionym napływu z żył wątrobowych po klasycznym zespoleniu Glenna, oraz przetrwanie jednostronnych płucnych przetok tętniczo-żylnych u pacjentów po operacji Fontana w wyniku takiej konfiguracji geometrycznej (TCPC, total cavopulmonary connection), która skutkuje jednostronnym napływem z żył wątrobowych. W tym ostatnim przypadku skuteczna w eliminacji płucnej przetoki tętniczo-żylnej jest rewizja układu fontanowskiego w celu eliminacji niekorzystnego „streamingu” z żył wątrobowych [12].

Kolejnym dowodem na rolę wątroby w powstawaniu nabytych płucnych przetok tętniczo-żylnych jest ich występowanie u pacjentów ze schyłkową postacią chorób wątroby - głównie marskością - i ich ustępowanie po transplantacji wątroby $[11,12]$. Objawy kliniczne tych przetok zależą od ich wielkości i liczby.

Płucne przetoki tętniczo-żylne są źródłem przecieku prawo-lewego z tętnic płucnych do żył płucnych, powodującego desaturację krwi tętniczej. Przepływ i ciśnienie płucne pozostają niezmienione i nie występuje przeciążenie objętościowe serca, w odróżnieniu od przetok w łożysku systemowym. Główne objawy to: sinica, policytemia i palce pałeczkowate. Często dochodzi do stopniowego nasilania się sinicy z powodu otwierania się nowych lub powiększania istniejących przetok. Czasami wysłuchuje się szmer ciągły lub skurczowy nad zajętym płucem. Powikłaniem moga być udary mózgowe i ropnie mózgu w mechanizmie zatoru skrzyżowanego, a także krwioplucie lub krwawienia do jamy klatki piersiowej, szczególnie u pacjentów z HHT [2, 6,12 ]. U wielu pacjentów (ok. 60\%) zaś nie obserwuje się żadnych objawów [16].

\section{Przetoki żylno-żylne}

Przetoki żylno-żylne mogą mieć charakter wrodzony lub nabyty. Domeną kardiologów pozostają nabyte przetoki żylno-żylne powstające u pacjentów z czynnościowo pojedynczą komorą po paliatywnych zespoleniach kardiochirurgicznych Glenna i Fontana. Takie połączenia są przyczyną przecieku prawo-lewego i hipoksemii w wyniku zmniejszenia efektywnego przepływu płucnego. Występuja u około 1/3 chorych po dwukierunkowym zespoleniu Glenna, u których rozwijają się w odpowiedzi na podwyższone ciśnienie żylne w górnej części ciała i służą dekompresji do systemu żyły głównej dolnej, żył wątrobowych lub żył płucnych [17] (ryc. 2). Mogą się pojawić w wyniku powstawania nowych lub poszerzenia istniejących naczyń, na

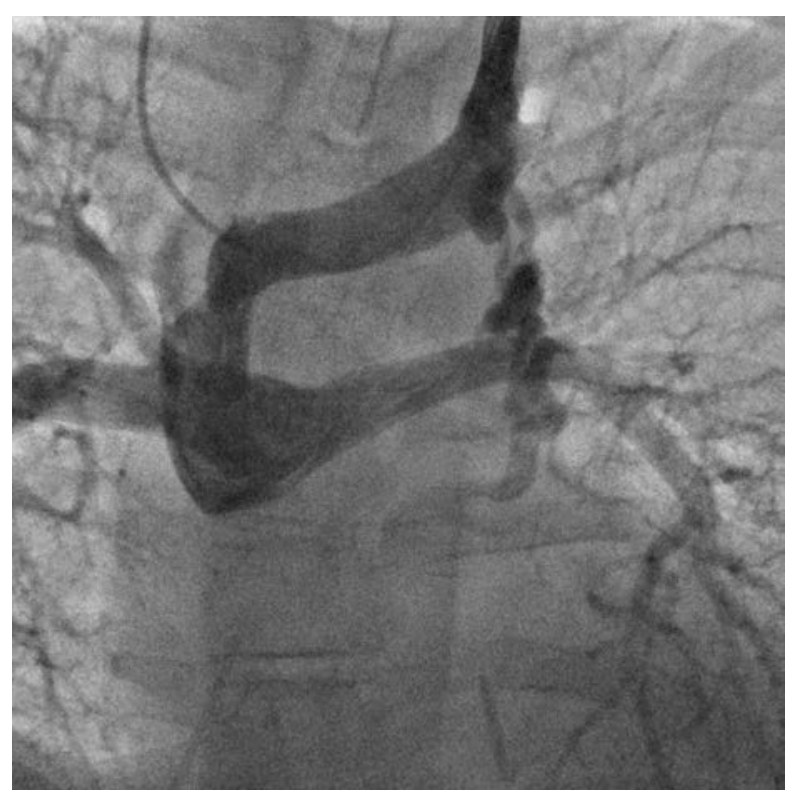

Rycina 2. Przetoka żyIno-żylna pomiędzy żyłą bezimienną a lewą żyłą płucną

przykład żyły głównej górnej lewej (ryc. 3), różnych połączeń żyły nieparzystej czy połączeń między żyłą bezimienną lub żyłą główną górną a żyłami płucnymi [17-19]. Chociaż istotne przetoki żylno-żylne są zazwyczaj zamykane przed końcowym etapem leczenia paliatywnego, to po operacji Fontana, w wyniku różnicy ciśnień między żyłami systemowymi i płucnymi, mogą się otwierać nowe połączenia, najczęściej drenujące bezpośrednio do żył płucnych lub przedsionka żył płucnych [19].

\section{Diagnostyka}

Nieinwazyjna diagnostyka obrazowa (ultrasonografia [USG], tomografia komputerowa [CT, computed tomography] i rezonans magnetyczny [MRI, magnetic resonance imaging]) odgrywa niezwykle ważną rolę w ustaleniu rozpoznania, ocenie rozmiarów anomalii naczyniowej i zaplanowaniu odpowiedniego leczenia.

Podstawowym badaniem jest doplerowskie badanie USG, w którym potwierdza się obecność przetoki tętniczo-żylnej dzięki ocenie charakteru i prędkości przepływów naczyniowych. Wadą jest jego ograniczona przydatność w ocenie zmian głęboko położonych.

U pacjentów z dużymi przetokami i objawami krążenia hiperkinetycznego w badaniu echokardiograficznym stwierdza się cechy przeciążenia objętościowego jam serca. Obecność przetoki wieńcowej sugeruje uwidocznienie poszerzonego proksymalnego odcinka tętnicy wieńcowej; często można również prześledzić przebieg przetoki do miejsca ujścia przy użyciu kolorowego doplera [2]. W przypadku 


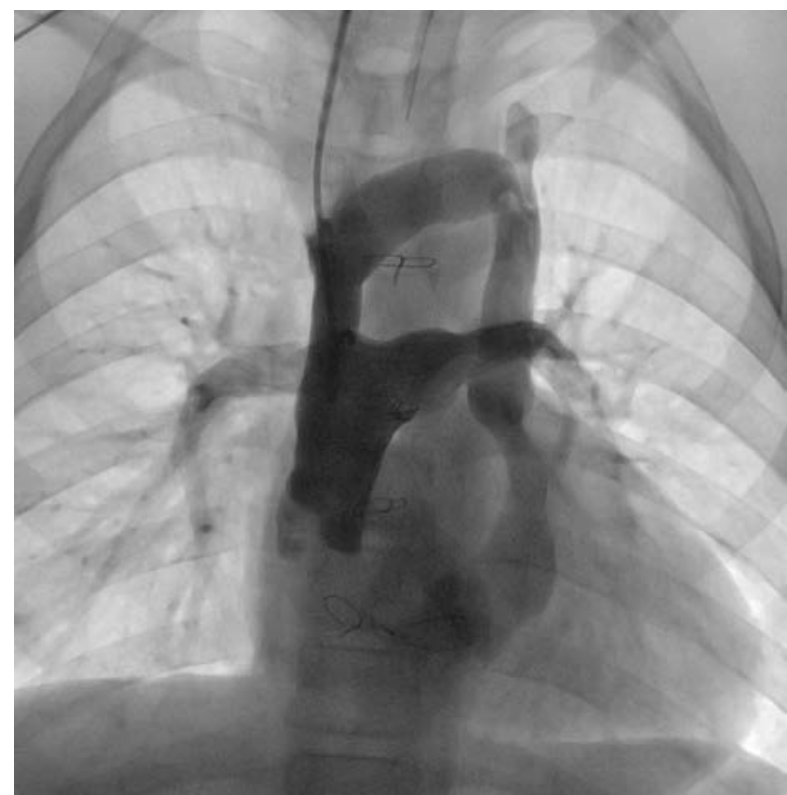

Rycina 3. Rekanalizowana lewostronna żyła główna górna drenująca do zatoki wieńcowej u pacjenta po zabiegu Glenna

płucnych przetok tętniczo-żylnych ważną rolę odgrywa echokardiografia kontrastowa. Przyjmuje się, że pojawienie się w lewym przedsionku pęcherzyków silnie wstrząśniętej soli fizjologicznej po 3-5 cyklach pracy serca świadczy o obecności przetok płucnych [12].

Tomografia komputerowa i MRI umożliwiają dokładną ocenę anatomiczną przetoki tętniczo-żylnej, typowo z uwidocznieniem wczesnego wypełnienia kontrastem żyły w czasie fazy tętniczej. Preferowaną techniką jest obecnie MRI, ponieważ nie wymaga użycia promieniowania jonizującego, a jednocześnie umożliwia ocenę przepływów. Tomografia komputerowa jest stosowana głównie w sytuacjach pilnych ze względu na krótki czas skanowania [6, 20, 21]. Angiografia inwazyjna jest wykonywana u pacjentów zakwalifikowanych do leczenia interwencyjnego.

\section{Leczenie przetok naczyniowych}

Bezwzględne wskazania do leczenia pacjentów z malformacjami naczyniowymi to: niedokrwienie związane z zespołem podkradania, nadciśnienie żylne powodujące objawy, upośledzenie funkcji narządu związane z efektem masy guza, niewydolność serca i krwawienia (np. z przewodu pokarmowego, układu moczowego) [2, 3].

Celem leczenia jest izolacja i zamknięcie miejsca komunikacji tętniczo-żylnej. Proste zamknięcie lub podwiązanie proksymalnej tętnicy doprowadzającej jest niewystarczające i przynosi efekt przeciwstawny do zamierzonego ze względu na szybki rozwój krążenia obocznego [3]. Wybór metody leczenia zależy od lokalizacji i typu malformacji naczyniowej.
Podstawową metodą leczenia przetok tętniczo-żylnych jest przezcewnikowa embolizacja z dostępu przez naczynie obwodowe lub bezpośrednie nakłucie zmiany. Leczenie chirurgiczne stosuje się jedynie wówczas, gdy mamy do czynienia z dobrze wyodrębnioną anomalią naczyniową i możliwe jest jej całkowite usunięcie [2]. Jest ono natomiast przeciwwskazane w przypadku złożonych przetok z wieloma doprowadzającymi i drenującymi naczyniami (ze względu na duże ryzyko nawrotu) oraz przetok położonych głęboko lub w bliskim sąsiedztwie istotnych struktur, które mogą zostać uszkodzone w trakcie zabiegu chirurgicznego [3].

Przezcewnikowa embolizacja jest najbezpieczniejszym dla pacjenta sposobem zamykania przetok naczyniowych [1]. Istnieje bardzo duża różnorodność materiałów embolizacyjnych, na przykład polimery i substancje płynne (np. klej cyjanoakrylowy lub Onyx ${ }^{\circledR}$ - kopolimer etylenu z alkoholem winylowym) oraz odpowiednie okludery mechaniczne (coile typu Gianturco ${ }^{\circledR}$, coile z kontrolowanym odczepianiem, mikrocoile, korki naczyniowe) $[3,18]$. Dobór odpowiedniego czynnika embolizującego zależy od typu nieprawidłowej komunikacji tętniczo-żylnej (wielkości, dynamiki przepływu, liczby i kalibru wszystkich tętnic doprowadzających i naczyń drenujących), a także od tego, czy zajęte naczynie musi być zachowane, czy można je poświęcić. Należy również rozważyć ewentualne ryzyko i konsekwencje niezamierzonej okluzji prawidłowych naczyń.

Najczęściej używanymi okluderami mechanicznymi są coile, czyli sprężynki wewnątrznaczyniowe i korki naczyniowe, takie jak amplatzer vascular plug (AVP) (ryc. 1). W celu uniknięcia powikłań należy dokładnie dobrać rozmiar okludera na podstawie badania angiograficznego. W przypadku zbyt małego okludera istnieje ryzyko jego migracji, natomiast zbyt duży może spowodować zamknięcie prawidłowego naczynia. Przy małych rozmiarach naczynia wybierane są coile, a naczynia o większych rozmiarach są zamykane korkami naczyniowymi (AVP). Większa sztywność systemu dostarczającego AVP w porównaniu z coilami w niektórych przypadkach może okazać się wadą [22]. Gdy istotne jest zachowanie przepływu przez zajęte naczynia albo jeśli komunikacja tętniczo-żylna jest typu „bok do boku”, wskazane jest użycie stentu powlekanego. W niektórych przetokach o bardzo szybkim przepływie wykorzystuje się czynniki płynne, które polimeryzują szybko (klej cyjanoakrylowy) lub w bardziej kontrolowany sposób (Onyx $\left.{ }^{\circledR}\right)$ [3].

Przetoki tętnic wieńcowych należy zamykać u pacjentów objawowych z istotnym lewo-prawym przepływem krwi i przeciążeniem objętościowym lewej komory, niewydolnością serca lub niedokrwieniem mięśnia sercowego [2, 8] oraz u pacjentów bezobjawowych z dużym przeciekiem w celu zapobiegania wystąpienia objawów lub powikłań, szczególnie w populacji pediatrycznej [8]. Nie należy zamykać niewielkich przetok, niepowodujących objawów i/lub powiększenia jam serca. Celem leczenia jest zamknięcie przetoki przy zachowaniu prawidłowego przepływu 
wieńcowego [2]. Leczenie przetok może być chirurgiczne lub przezskórne. Aktualnie preferowane jest zamykanie przetok metodami kardiologii interwencyjnej. Możliwe powikłania zabiegu interwencyjnego to: migracja coila w wyniku szybkiego przepływu w przetoce lub niewłaściwego dobrania jego rozmiaru, propagacja skrzepu do prawidłowego naczynia, przejściowe zmiany elektrokardiograficzne lub zawał serca $[9,10]$.

W przypadku płucnych przetok tętniczo-żylnych wskazaniem do interwencji jest istotna sinica lub przebyty incydent zatorowy. U chorych bezobjawowych rekomendowane jest zamykanie przetok, w których średnica naczyń doprowadzających wynosi powyżej $3 \mathrm{~mm}$, ze względu na duże ryzyko udaru i innych zatorów systemowych $[2,11]$. Możliwe powikłania związane z interwencyjnym zamykaniem płucnych przetok tętniczo-żylnych to: krwotok, zator paradoksalny, infekcja, zawał płuca, nadciśnienie płucne, zator powietrzny, zakrzepica żył głębokich spowodowana dostępem naczyniowym [23]. Częstość rekanalizacji po wstępnej skutecznej embolizacji wynosi 5-15\%. Ponadto mogą się rozwijać nowe przetoki, a małe mogą się powiększać [11]. Pacjenci z rozsianymi mikroskopijnymi płucnymi przetokami tętniczo-żylnymi zasadniczo nie kwalifikują się do leczenia interwencyjnego. U części pacjentów, szczególnie w przypadku bardzo dużych przetok, najkorzystniejszą formą leczenia jest zabieg chirurgiczny polegający na usunięciu zmiany z zachowaniem jak największego obszaru zdrowego płuca [2, 11, 22]. Pacjenci z płucnymi przetokami tętniczo-żylnymi, które powstały po operacji dwukierunkowego Glenna albo operacji Kawashima, odnoszą korzyść po włączeniu spływu żył wątrobowych do krążenia płucnego $[11,12,15]$. Opisywano również ustępowanie płucnych przetok tętniczo-żylnych po ortotopowej transplantacji serca u pacjentów po operacji Fontana [12] i Kawashimy [11].

$\mathrm{U}$ chorych po zespoleniu Glenna postępowanie w przypadku przetok żylno-żylnych zależy od ich przebiegu i od tego, czy pacjent będzie poddany operacji Fontana. U osób, u których planowana jest konwersja zespolenia Glenna do zespolenia Fontana, połączenia żylno-żylne podprzeponowe nie są zamykane, ponieważ ich wpływ na saturację krwi tętniczej po komplementacji krążenia fontanowskiego jest nieistotny. Natomiast przetoki drenujące pośrednio lub bezpośrednio do przedsionka powinny być zamykane, mogą się bowiem stać przyczyną znaczącej desaturacji. Jeżeli zabieg Fontana nie może być wykonany lub musi być odroczony, należy zamykać wszystkie istotne, powodujące desaturację przetoki, niezależnie od ich przebiegu [22]. Ostatnio podaje się w wątpliwość celowość zamykania małych przetok żylno-żylnych u chorych po operacji Fontana, ponieważ skutkuje ono istotną poprawą saturacji jedynie u nielicznych pacjentów [22]. Na uwagę zasługuje również doniesienie o zwiększonej śmiertelności u takich osób w obserwacji 5-letniej w porównaniu z chorymi, u których nie wykonano zabiegu embolizacji. Według autorów należy zachować szczególną ostrożność przy kwalifikacji do zamykania przetok żylno-żylnych pacjentów po operacji Fontana o typie bezpośredniego połączenia przedsionka z tętnicą płucną, z zespołem heterotaksji i z ciśnieniem w układzie fontanowskim powyżej $18 \mathrm{~mm} \mathrm{Hg}$ [24].

\section{Podsumowanie}

Przetoki naczyniowe to nieprawidłowe bezpośrednie połączenia naczyniowe, przez które przepływa krew z pominięciem łożyska włośniczkowego. Mogą być przyczyną istotnych zaburzeń miejscowych i ogólnych w zależności od lokalizacji anatomicznej, wielkości i typu. Domeną kardiologów pozostają przede wszystkim przetoki powodujące takie objawy, jak niewydolność serca z wysokim rzutem czy sinica. Szczególną grupę stanowią przetoki powstające u pacjentów ze złożonymi siniczymi wadami serca po paliatywnych zespoleniach kardiochirurgicznych. Większość przetok może być bezpiecznie i skutecznie zamykana przy użyciu różnych metod embolizacji przezcewnikowej; znacznie rzadziej jest konieczne leczenie chirurgiczne.

\section{Konflikt interesów}

Autorzy nie zgłaszają konfliktu interesów.

\section{Abstract}

Vascular fistulas are irregular congenital or acquired vascular connections. Due to their diverse clinical manifestations, depending on their location and morphological nature, they are dealt with by medical doctors of various specialties. This article aims to present the most common types of fistulas of interest to cardiologists, in terms of their etiology, symptoms and contemporary methods of diagnosis and treatment.

Key words: vascular fistulas, cardiology, percutaneous treatment

Folia Cardiologica 2017; 12, 5: 510-516 


\section{Piśmiennictwo}

1. Skalski JH, Kovalenko I. Przetoki naczyniowe. In: Skalski JH, Religa Z. ed. Kardiochirurgia dziecięca. Wydawnictwo Ślask, Katowice 2003: 381-391.

2. Szymański P. Wrodzone malformacje naczyniowe i nabyte przetoki. In: Hryniewiecki T, Gąsior Z, Rużyło W. ed. Wady serca. Medical Tribune Poland, Warszawa 2013: 633-646.

3. Patel R, Nicholson AA. Arteriovenous fistulas: etiology and treatment Important considerations from initial evaluation to treatment planning. Endovasc Today 2012: 45-51.

4. Imran $\mathrm{T}$, Hashim $\mathrm{H}$, Beidas $\mathrm{AK}$, et al. A covert complication of arteriovenous fistulas. J Cardiol Cases. 2015; 11(5): 132-135, doi: 10.1016/j.jccase.2015.01.004.

5. Jones BV, Ball WS, Tomsick TA, et al. Vein of Galen aneurysmal malformation: diagnosis and treatment of 13 children with extended clinical follow-up. AJNR Am J Neuroradiol. 2002; 23(10): 1717-1724, indexed in Pubmed: 12427630.

6. González SB, Busquets JC, Figueiras RG, et al. Imaging arteriovenous fistulas. AJR Am J Roentgenol. 2009; 193(5): 1425-1433, doi: 10.2214/AJR.09.2631, indexed in Pubmed: 19843763.

7. Gallego C, Velasco M, Marcuello $P$, et al. Congenital and acquired anomalies of the portal venous system. Radiographics. 2002; 22(1): 141-159, doi: 10.1148/radiographics.22.1.g02ja08141, indexed in Pubmed: 11796904.

8. Gowda RM, Vasavada BC, Khan IA. Coronary artery fistulas: clinical and therapeutic considerations. Int J Cardiol. 2006; 107(1): 7-10, doi: 10.1016/j.ijcard.2005.01.067, indexed in Pubmed: 16125261.

9. Qureshi SA. Coronary arterial fistulas. Orphanet J Rare Dis. 2006; 1: 51, doi: 10.1186/1750-1172-1-51, indexed in Pubmed: 17184545.

10. Latson LA. Coronary artery fistulas: how to manage them. Catheter Cardiovasc Interv. 2007; 70(1): 110-116, doi: 10.1002/ccd.21125, indexed in Pubmed: 17420995.

11. Papagiannis J, Apostolopoulou S, Sarris Ge, et al. Diagnosis and management of pulmonary arteriovenous malformations. Images Paediatr Cardiol. 2002; 4(1): 33-49, indexed in Pubmed: 22368610.

12. Kavarana MN, Jones JA, Stroud RE, et al. Pulmonary arteriovenous malformations after the superior cavopulmonary shunt: mechanisms and clinical implications. Expert Rev Cardiovasc Ther. 2014; 12(6): 703-713, doi: 10.1586/14779072.2014.912132, indexed in Pubmed: 24758411.

13. Nozaki T, Nosaka S, Miyazaki O, et al. Syndromes associated with vascular tumors and malformations: a pictorial review. Radiographics. 2013; 33(1): 175-195, doi: 10.1148/rg.331125052, indexed in Pubmed: 23322836.
14. Malec E, Januszewka K. Pacjenci z pojedyncza komora po operacji Fontana - nowe wyzwanie dla kardiologów. Kardiol Pol. 2010; 4 : 467-471.

15. Mroczek T, Jarosz J, Skalski JH. Włączenie spływu z żył wątrobowych do układu płucnego u dzieci z zespołem heterotaksji po zespoleniu żylno-płucnym. Kardiochir Torakochir Pol. 2009; 6(1): 34-37.

16. Tang SE SE, Akbar FA, Tan BP, et al. Amplatzer vascular plug in occlusion of a pulmonary ateriovenous malformation. Asian Cardiovasc Thorac Ann. 2017; 25(4): 310-312, doi: 10.1177/0218492317709696, indexed in Pubmed: 28492337.

17. Magee AG, McCrindle BW, Mawson J, et al. Systemic venous collateral development after the bidirectional cavopulmonary anastomosis. Prevalence and predictors. J Am Coll Cardiol. 1998; 32(2): 502-508, doi: 10.1016/s0735-1097(98)00246-0, indexed in $\mathrm{Pu}$ bmed: 9708483

18. Walsh KP. Advanced embolization techniques. Pediatr Cardiol. 2005 26(3): 275-288, doi: 10.1007/s00246-005-1012-6, indexed in Pubmed: 16082573.

19. Kreutzer J, Graziano JN, Stapleton G, et al. Late catheter interventions in hypoplastic left heart syndrome. Cardiol Young. 2011; 21 Suppl 2: 65-76, doi: 10.1017/S1047951111001612, indexed in Pubmed: 22152531.

20. Hyodoh $\mathrm{H}$, Hori $\mathrm{M}$, Akiba $\mathrm{H}$, et al. Peripheral vascular malformations: imaging, treatment approaches, and therapeutic issues. Radiographics. 2005; 25(Suppl 1): S159-S171, doi: 10.1148/rg.25si055509, indexed in Pubmed: 16227489.

21. Lowe LH, Marchant TC, Rivard DC, et al. Vascular malformations: classification and terminology the radiologist needs to know. Semin Roentgenol. 2012; 47(2): 106-117, doi: 10.1053/j.ro.2011.11.002, indexed in Pubmed: 22370189.

22. Girona J, Martí G, Betrián P, et al. Percutaneous embolization of vascular fistulas using coils or Amplatzer vascular plugs. Rev Esp Cardiol. 2009; 62(7): 765-773, doi: 10.1016/s1885-5857(09)72357-6, indexed in Pubmed: 19709512

23. Swanson KL, Prakash UB, Stanson AW. Pulmonary arteriovenous fistulas: Mayo Clinic experience, 1982-1997. Mayo Clin Proc. 1999; 74(7): 671-680, doi: 10.4065/74.7.671, indexed in Pubmed: 10405695.

24. Poterucha JT, Johnson JN, Taggart NW, et al. Embolization of veno-venous collaterals after the fontan operation is associated with decreased survival. Congenit Heart Dis. 2015; 10(5): E230-E236, doi: 10.1111/chd.12276, indexed in Pubmed: 26010433. 